\title{
The Incipient Fertility Transition and Women's Labor Force Participation in Sub-Saharan Africa, 1991-2005: Evidence From the Demographic and Health Surveys
}

\author{
Fatou Jah \\ Population Media Center \\ P.O. Box 547, Shelburne, VT 05403 \\ Email: fatou.jah@gmail.com/fjah@populationmedia.org \\ Tel.: +1(607) 379-9259
}

\begin{abstract}
Sub-Saharan Africa has experienced an expansion of schooling, accompanied by delays in marriage and lower fertility. These trends stand to boost women's employment prospects and foster further fertility decline through a variety of plausible mechanisms. But the evidence has been spotty. Building on the diversity of recent fertility changes within countries and taking advantage of repeat nationally representative and comparable DHS surveys, we attempt a large-scale historical analysis to provide an early assessment of the status of the transition in 21 countries. To evaluate the prospects for further declines in the region, we use multiple techniques to quantify the effect of fertility on employment as well as its contribution relative to other factors to observed changes in women's employment within countries. Results show a growing negative relationship in some countries and no relationship in others. Implications for the transition and inequality in the region are discussed.
\end{abstract}

Keywords: Incipient fertility transition; overall employment; skilled employment; sub-Saharan Africa; fertility employment regimes

\section{Résumé}

L'on assiste aujourd'hui à une expansion de la scolarité en Afrique subsaharienne, accompagnée de mariages plus tardifs et d'une baisse de la fertilité. Ces tendances promettent d'améliorer les perspectives d'emplois des femmes et de contribuer davantage au déclin de la fertilité à travers une variété de mécanismes plausibles. Mais l'évidence de ce phénomène reste encore lacunaire. En me basant sur divers changements récents dans le taux de fertilité en différents pays et en exploitant des données de sondages représentatifs et nationaux sur la démographie et la santé, j'entreprends une analyse historique à grande échelle en vue de fournir une évaluation préliminaire de la transition en cours dans 21 pays. Afin de mesurer les perspectives de déclins supplémentaires dans la région, l'étude utilise plusieurs méthodes pour quantifier les effets absolus et relatifs de la fertilité dans les métiers généraux de même que qualifies. Les résultats démontrent une relation négative qui va en diminuant au fil du temps dans quelques pays et ne montrent aucun rapport dans d'autres, peu importe le secteur d'emploi. Les implications pour la transition et de l'inégalité dans la région sont discutées.

Mots clé: Transition naissante de la fertilité; de l'emploi total; l'emploi qualifié; l'Afrique subsaharienne; les régimes d'emploi de la fertilité 


\section{Introduction}

The last three decades have seen a global expansion of schooling, especially female schooling across the developing world including sub-Saharan Africa (SSA) (Lloyd and Hewett 2003; UNICEF 2003). In SSA as elsew here in the developing world, this expansion in schooling has been accompanied by changes in fertility behavior (Bongaarts 2002, 2006, 2007; Cohen 1998; Eloundou-Enyegue et al. 2000; Garenne and Joseph 2002; Shapiro and Gebreselassie 2008; Shapiro, Gebreselassie and Strunk 2003; Shapiro and Tambashe 2002; Rutstein 2002) as well as nuptiality (NAS 2005; Westoff 2003), challenging the notion that African fertility regimes are resistant to transition to lower fertility. O verall, based on more than one wave of Demographic and Health Surveys (DHS) data (DHS 2013), countries that have registered declines include in the order of lowest TFR and most recent decline: Lesotho, 3.3 (2009); N amibia, 3.6 (200607); Zimbabwe, 3.8 (2005-06); Ghana, 4.0 (2008); Gabon, 4.1 (2012); Kenya, 4.6 (2008-09); Rwanda, 4.6 (2010); Nigeria, 4.7 (1999); Cameroon, 4.8 (1998); Eritrea, 4.8 (2002); Ethiopia, 4.8 (2011); Madagascar, 4.8 (2008-09); Senegal, 4.9 (2008-09); Cote d'Ivoire, 5.2 (1998-99); Liberia, 5.2 (2007); Togo, 5.2 (1998); Tanzania, 5.4 (2010); Benin, 5.6 (2001); Malawi, 5.7 (2010); Burkina Faso, 5.9 (2003); Zambia, 5.9 (2001-02); U ganda, 6.2 (2011); Chad, 6.3 (2004); Burundi, 6.4 (2010); Mali, 6.6 (2006); and Niger, 7.0 (2006). However, residential variation within countries in the nature of the transition has been noted. In addition to the importance of educational differences emphasized by Shapiro and Tambashe (2002), they describe the African fertility transition as a three-stage process, initiated first in urban areas, then at a slower pace in rural areas and finally with the pace in rural areas overtaking that initially observed in urban areas. This final stage in the process can be explained by the fact that at some point in the transition rural places provide more room for further fertility declines.

Further, a historical examination of the multiwave survey data reveals substantial country diversity over the course of the fertility transition (DHS 2013). Several countries (Benin, Burkina Faso, Cameroon, Liberia, Nigeria, Senegal, Zambia and Zimbabwe are currently experiencing stalls after consistent fertility declines while many more (Burundi, Chad, Cote d'Ivoire, Eritrea, Ethiopia, Gabon, Madagascar, Malawi, Lesotho, Namibia and Togo) have consistently registered declines since the onset of their transition. Still and highlighting further diversity, other countries have resumed their transition following prior stalls (Ghana, Mali, N iger, Kenya, Rwanda, Tanzania, and U ganda).

Guinea and Mozambique are stand-alone countries, in that they have not experienced any fertility decline. Indeed, in both countries, fertility has been rising: from 5.5 in 1999 to 5.7 in 2005 in Guinea and in Mozambique, from 5.2 in 1997 to 5.9 in 2011.

These trends, to be precise, reduced fertility is expected to boost women's employment prospects, which in turn, should foster further fertility decline through a variety of plausible mechanisms. Some of these effects have been recognized in the theoretical literature to work through competition for mother's time, increased access to contraception, growing propensity to trade quantity for quality, or greater leverage in family planning decisions (C aldwell 1980, 1982; Eloundou-Enyegue 1997; Mason and Palan 1981; Stycos and Weller 1967). Yet, the impacts of these demographic trends remain understudied in developing countries. Despite the variety of cogent arguments about why African fertility transitions could yield socioeconomic dividends at the individual and national levels, the evidence has been spotty. This paucity itself reflects a number of limitations in theory, data availability, research design, and substantive focus.

The purpose of this research is to address some of the above limitations. I take advantage of the continued accumulation of nationally representative and comparable DHS to provide an early assessment of the fertility transition in SSA. Building on recent changes within countries and the diversity of national experiences (Bongaarts 2007; Shapiro and Tambashe 2002; Shapiro and Gebreselassi 2008), the study attempts a large-scale empirical analysis to document the status and evolution of contemporary African fertility transitions between 1991 and 2005. To evaluate the prospects for further fertility declines in the region, I examine the effect of fertility on women's employment in the region within the same period of study. Specifically, I quantify the effect of changes in individual fertility versus changes in the effect of total fertility rates (TFRs) or changes in the effect of country-specific processes on which employment opportunity depend. Individual fertility reflects family size while TFRs reflects aggregate fertility levels and for the purpose of this research is synonymous with the transition. Countrywide processes that influence employment opportunity are factors that create demand for employment such as the availability of employment structures and 
accessible child-care facilities supported by the enforcement of women-friendly employment policies.

Q uantifying the relative contribution of fertility within African labor markets is timely given the reported stalls in the transition in several countries (Bongaarts 2006; Shapiro and Tambashe 2002; Shapiro and Gebreselassi 2008). Similarly, the lack of adequate country progress on the MDGs in Africa, the United $\mathrm{N}$ ations blue-print for development through the eradication of poverty, hunger, malnutrition, disease and gender inequality in society, among others, has been reiterated in the development policy arena (United N ations 2005). Large-scale systematic research to inform policy on these fronts is imperative.

\section{Theoretical Framework and Literature Review}

The theory of the economics of fertility (Becker 1992) and the demographic role incompatibility thesis (Collver and Langlois 1962; Mason and Palan 1981; Stycos and Weller 1967) offer two theoretical frameworks for examining how fertility relates to employment. The maternal role incompatibility thesis is premised on the conflict between childrearing and paid work. Because childrearing remains primarily the responsibility of women, the theory posits that women are less likely to continue employment following childbearing (Collver and Langlois 1962; Youssef 1972). Thus, childrearing is associated with less labor market activity for women due to frequent temporary or longer withdrawals from employment (Collver and Langlois 1962; Youssef 1972). Proponents predict that with growth in labor demand stemming from modernization and industrialization, women will reduce their fertility to take advantage of paid employment, which in turn, will lead to further fertility declines in the aggregate. 0 ther theorists have qualified the thesis, suggesting that it only holds where conflict between time demands of working and mothering arises (Mason and Palan 1981; Stycos and W eller 1967). Mason and Palan (1981) have elaborated on the sources of this conflict. For them, mothers' employment is determined by both the structure and organization of the labor market as well as norms relating to the organization of childrearing and other household responsibilities. These qualifications are important for this study because the time costs of childrearing may not rest squarely on mothers but spread to family members or extended networks. Yet, empirical studies testing the thesis on African data, especially recent data are scant.
Contrasting the role incompatibility thesis that emphasizes non-economic factors, the economics of fertility theory places a higher premium on economic penalties arguing that women's rising economic activity increases the relative cost of children, which in turn, reduces the demand for children (Becker 1992). Applying this thinking in African settings, childbearing costs for employed women are expected to induce fertility transition (Becker 1992). While Becker's economic theory of fertility has wide appeal in social science research because of its ability to explain a wide range of family transformations, like the demographic role incompatibility thesis, it has not been systematically evaluated in the African context.

The relationship between fertility and employment is central to demography precisely because of its impact on fertility transition in developed and developing regions alike. Accordingly, it has been studied extensively at both the micro and macro levels in developed countries. Although the fertility-employment relationship at the micro-level in the West has been largely negative, albeit reported gradual reversal in the direction from macro studies (e.g., Brewster and Rindfuss 2000), the micro-evidence on developing countries is mixed. Schockaert (2005) provides a review of existing studies in Latin America. Consistent with the developed country evidence, some researchers find the association between fertility and employment to be negative (e.g., Connelly, DeGraff and Levison 1996 for Brazil). Others find no relationship (Stokes and Hsiah 1984 for Taiwan) while Gurak and Kritz (1982) find no relationship in the short term but find a positive link over the long term in the Dominican Republic.

Shifting to SSA, this study's region of focus, the evidence is scant. A handful of studies using SSAn data (Beguy 2009; Lokshin, Glinskaya, and Garcia 2000; Shapiro and Tambashe 1997) provide evidence on the relationship at the micro-level. Lokshin et al. (2000) examine, beyond other factors, the connection between employment and cost of childcare in Kenya. These authors find that fertility (indirectly based on increases in institutionalized childcare costs) negatively impacts employment. Shapiro and Tambashe (1997) examine the linkages between schooling, employment, and lifetime fertility differentials in Kinshasa, the Democratic Republic of Congo. They observe modern sector workers to significantly display lower fertility than informal sector workers (i.e., a work fertility conflict) and conclude that both education and 
employment status will be critical to a sustained fertility decline. Thus the evidence from both studies lends support to the incompatibility thesis. Using event history data to examine the impact of employment on fertility in two culturally different urban settings - Dakar (Senegal) and Lome (Togo) Beguy (2009) finds a role conflict in Lome but not in Dakar, pointing to the well-debated role of context on the relationship.

Sharply contrasting the industrialized world, comparative evidence on the work-fertility relationship in developing countries as a whole is rare, with the only evidence based on the United $N$ ations analysis of the 1970s World Fertility Survey data (United Nations 1987; Lloyd 1991). The evidence that emerged from these data, largely inconsistent with the more recent single country African studies (Lokshin et al. 2000; Shapiro and Tambashe 1997), found the fertility-employment link to be much weaker in SSA, with no clear-cut difference across occupation sectors, even as the link was reportedly negative, especially in modern and mixed occupations in Latin America, Asia and $O$ ceania (U nited $\mathrm{N}$ ations 1987). The inconsistency in the evidence between the older U nited Nations Study and the more recent studies on SSA can be explained by the fact that the older study included only six African countries, different from those investigated in the recent studies. Given that SSA was and still is considered the least developed of the regions covered, the United Nations study concluded that the fertility-employment relationship as well as the mediating factors of marriage, schooling and women's status, are dependent on level of development. But this evidence is dated.

A recent cross-country analysis of the effect of fertility on employment conducted by Bloom, Canning, Fink and Finlay (2009) is consistent with the United Nations (1987) results. However, this latter study is global, including developed and developing countries. Against this background, largescale literature on the work-fertility relationship focusing on Africa has been sparse, partly due to a perceived weak link between the two variables and partly due to, until recently, data scarcity.

The existing few micro studies on the question of how fertility relates to employment in SSA have generally indicated the existence of a work family conflict for mothers (Lokshin et al. 2000; Shapiro and Tambashe 1997). Such evidence is quite contrary to the evidence from macro studies that show no clear-cut link between fertility and employment (Bloom, C anning, Fink and Finlay 2009;
Lloyd 1991; United Nations 1987). Together, the studies provide valuable insights on how the relationship has evolved. At the same time, caution is warranted in generalizing the studies. The research design and methods used in each of the reviewed studies differ and coupled with differences in study timing, comparing the findings can prove to be difficult. For instance, Beguy (2009) measured fertility by pregnancy spacing, Shapiro and Tambashe (1997) measured fertility by number of children ever born while Lokshin, Glinskaya, and Garcia (2000) had yet another different measure: cost of childcare. By the same token, different forms of employment are considered by each of these studies.

This study's contribution to the scant SSAn literature on the subject is unique in several respects. First, in examining recent DHS data on a wider range of African countries than previously studied, it provides a first comprehensive assessment of the question of how the incipient fertility transition in the region has impacted women's employment prospects to inform the transition across the region. The use of this large number of countries helps overcome questions about contextual variation. Second and tied to the first contribution, it is the first large-scale study of its kind to test the applicability of the role incompatibility hypothesis in modern sector work in the African context.

Third, it permits comparison and generalization of the evidence through the use of comparable nationally representative data from the same source (the DHS Program) collected around similar time periods and replicating the entire analyses across all the countries. Using a common data source as the DHS that employs standardized research designs and methodologies that have undergone considerable improvement over the years (DHS 2013) across the developing world partly overcomes many concerns over data quality and differences in study design, conceptualization and definition of key variables. Fourth, beyond differentiating the overall from the skilled sector, it considers a rich set of individual and household correlates that bear on women's employment to permit isolating the direct effect of changes in fertility on changes in employment.

The fifth contribution of this study is in the realm of research methodology. Q uantifying the gains from social interventions has been particularly difficult due to unavailability of data needed to establish causality and the possibility of reverse causation (Cramer 1980; Moffitt 2003; 2005). Excluding Beguy's (2009) 
study, the reviewed African evidence on the question comes from cross-sectional single-period data. That cross-sectional analysis is insufficient to infer causal influence has been well established (Thornton 2001), especially in the case of crosscountry correlations of women's employment (see Jah 2007). Further, macro-level analyses assume compositional homogeneity across individuals while micro-level analyses ignore country-specific influences. A reliance on either approach is unsatisfactory (Eloundou-Enyegue 2011) as interpretations based solely on either are likely to suffer from ecological fallacy (Eloundou-Enyegue 2011; Robinson 1950).

Three methodological attempts are made to help address the issues of causal inference. The first is through the use of historical data to address the issue of temporal fallacy, thereby partly addressing concerns over causality. The second is through the triangulation of different analytical methods to refine interpretation and enhance confidence in the findings. Third, in recognition that women's employment is governed by both individual characteristics and the institutional context (Schockaert 2005), the study marries the macro and micro approaches in two unique ways: 1) analyzing individual-level data within each country but using country-period as the unit of analysis and 2) classifying these countries into employment regimes on the basis of country's average fertility and employment profiles. Thus, generalization without loss of contextual specificities is achieved.

\section{Data and Methods}

\section{Data}

This study takes advantage of the availability of multiple waves of comparable and nationally representative cross-sectional data from the DHS Program to embark on a large-scale study. O ne unique feature of the study is the construction of a large historical data set containing over 404,000 cases to provide analytical rigor, enhance interpretations and document change by comparing the historical experiences of 21 SSAn countries. The DHS female respondents' files were used to construct the data set containing information on women's schooling, marriage, fertility, and labor market outcomes, as well as their background characteristics. O ne caveat in this dataset is worth noting. While it is interesting to examine the demographic outcomes and employment experiences of both women and men, the male information available at the time of this study was mostly derived from a sub-sample of men (the husbands/partners of married women only) and therefore does not provide a representative sample of the population of men. Another caveat is that the survey data are cross-sectional even though the repeat waves within countries permit the construction of a historical dataset.

This historical data covers two periods ${ }^{1}$ within each country. The first period spans 1991 to 1997 , while the second study spans 1997 to 2005 and is based on the most recent survey in a particular country at the time of the study. Given the study's emphasis on historical changes and data comparability, only countries with repeat surveys conducted from 1991 onwards were analyzed. Older surveys were not standardized across countries and some key variables were measured differently than from the 1990s on. This selection criterion yielded a sample of 21 countries: eight in West Africa (Benin, Burkina Faso, Cote d'Ivoire, Ghana, Mali, Niger, Nigeria, and Senegal); two in Central Africa (Cameroon and Chad); and eleven in Eastern Africa (Ethio pia, Kenya, Madagascar, Malawi, Mozambique, N amibia, Rwanda, Tanzania, U ganda, Zambia, and Zimbabwe). Southern Africa is not represented because the countries did not meet the above criterion. With the exception of this latter region, the sampled countries provide adequate representation of the continent.

\section{Measures}

The study's main goal was to estimate the contribution of declining fertility versus general processes of modernization (which depend mostly on economic growth) to changes in women's labor force participation since 1990, controlling for key correlates of employment. All the variables used: dependent, independent, and correlates, are fixed measures in each of the two survey periods used to construct the historical data in that they refer to the respondent's current status on that measure. This is an unavoidable caveat given the cross-sectional nature of the DHS surveys.

The dependent variable in all the analyses is labor force participation in the (1) overall and (2) skilled employment sectors. Overall employment is measured dichotomously by paid employment in any sector, coded "1" with non-employment or engagement in agricultural activity ${ }^{2}$ or unpaid family-

\footnotetext{
${ }^{1}$ The first period is used interchangeably with the first, earlier or initial study. Similarly, the second period is synonymous with second, later, or last study.

${ }^{2}$ Classifying activity in the agricultural sector as nonemployment is not to devalue women's work in this important employment domain but because of the
} 
work as the reference category and coded " 0 ". Skilled employment ${ }^{3}$ is also measured dichotomously by the proportion of employed individuals in professional, technical, and managerial as well as in skilled manual work and coded as "1". Thus, conditional on being in paid employed, this outcome models skilled economic activity against all other non-agricultural paid participation, the reference (coded "0"). Given that overall employment includes all non-agricultural paid work outside the home and makes no distinction between occupation sectors it should have lower human capital requirements for access and success, and present minimal work family conflict. Since the African public sector, more than the informal sector, is dwindling, overall employment should closely resemble informal work. On the other hand, skilled employment denotes more regulated occupation types with greater human capital prerequisites; it should therefore provide a closer measure of formal or modern sector work. A finer occupational distinction within formal and informal sectors is desirable, particularly in the latter sector where women are overrepresented. However, the occupation classification adopted by the DHS precludes such level of distinction.

Fertility is the explanatory variable in this study. It is measured as a continuous variable, based on the number of living children born to a respondent. A quadratic term was also added to address possible non-linearity. Although this measure adjusts for mortality - making it preferable to "total children ever born to a woman"- it does not distinguish between ages of children. Thus, when used to estimate the relationship between fertility and employment, it assumes that children of all ages influence mother's opportunity to work in the same way. This assumption overlooks the incompatibility theory that posits that children of pre-school age to pose greater work-childrearing conflict than children of school age and older. This concern is partly addressed in the analyses by controlling for "whether the respondent experienced a live birth in the year prior to the survey" discussed in further detail below under the section on correlates.

Drawing on the theoretical and past studies reviews, the study controls for several correlates of

conceptualization of the study wherein the work incompatibility thesis is being tested.

${ }^{3}$ Given that the skilled sector as used in this study is a subset of the overall employment, future analysis will employ the distinction "modern sector" versus "selfemployment." employment, reflecting four sets of influences that are likely to affect labor force participation. Four sets of correlates regarding basic information $n^{4}$; family composition or structural characteristics ${ }^{5}$; economic

\footnotetext{
${ }^{4}$ The basic correlates include age and its quadratic term, schooling and its quadratic term and marital status. Controlling for age, beyond its direct effect on employment, indirectly adjusts for experience, which is not asked in the DHS surveys. Age is measured by the number of completed years lived by the survey year. ${ }^{5}$ Family characteristics include four variables. The first measures whether the respondent had a birth in the year before the survey. As indicated earlier, a recent birth event is more relevant to women's employment transitions than family size, at least from a time competition perspective. On the other hand, the presence of other female adults in the household is expected to relieve some of this time conflict thereby facilitating a mother's outside paid work and is therefore controlled for (Gurak and Kritz 1996). The third correlate in this group is whether or not the respondent is wife of the household head. Being the wife of the household head is expected to be inversely related to a woman's paid work for several reasons, including household responsibilities, husband's economic support acting as a deterrent, and husband's opposition to her outside work. While urban settings offer greater work opportunities than rural ones, residence in an urban location can reduce potential childcare and household help from extended kin. Its effects can therefore be either negative (reflecting household structural effects) or positive (reflecting community effects). The fourth correlate therefore controls for whether she resides in an urban versus rural setting.
} 
constraints and the need to work ${ }^{6}$; and cultural attributes ${ }^{7}$ were controlled for.

\section{Methods}

The study adopts an innovative analytical approach in which the unit of analysis is country-period (to determine change across the two periods studied) even though input data are individual-level. As alluded to earlier, two levels of analyses: macro (using cross-country correlations) and micro (multivariate analyses) are conducted. The macrolevel analyses focused on cross-country correlations at three levels of successive complexity. In line with the existing aggregate evidence in the sociodemographic literature, a standard cross-country correlation between fertility and employment was first attempted followed by a cross-country correlation between changes in the two variables over the period under study (1991-2005). Lastly, country specific correlations of fertility and employment were done over the same period. Because cross country associations tend to mask compositional differences and factors likely to be influential at the individual level, micro-level multivariate regressions were conducted to further refine analyses. These micro-level analyses proceeded in two stages, employing two different

\footnotetext{
${ }^{6}$ Economic constraints include four variables. Two of these variables measure husband's education and work status. Both variables can work in either direction, negative (discouraging women's work where spouse's educational and occupational status is high enough to provide for family economic needs) or positive (fostering greater openness to women's changing family and economic roles and therefore support wife's economic activity). The third control, whether respondent's spouse resides with her, is expected to reduce economic constraints on the mother and her need to seek paid employment. But sub-regional variation in the effect of co-residential status of husbands stemming from differences in family systems (Caldwell 1987) is expected. The fourth variable is family socio-economic standing, measured by a socio-economic index derived from a factor analysis of aggregated household amenities and assets. An inverse association is presumed to exist between the index and informal employment, especially in situations where returns to human capital are low. Contrastingly, high family status is presumed to be influential in women's access to prestigious or formal occupations.

${ }^{7}$ The cultural set of correlates is measured by two variables: the respondent's ideal number of children and her approval of family planning. These variables are intended to capture changing perceptions. Again, like husband's co-residential status, these measures are expected to vary by family system across countries/subregions.
}

analytical techniques of increasing complexity: logistic regressions and regression decomposition. The micro-level analyses were replicated within each of the sampled countries.

Given their dichotomous nature, logistic regression appropriately estimates the two outcomes, overall and skilled employment. In the first stage, ordinary logistic regression was used to estimate the bivariate effects (i.e., without considering any controls). Next, the gross (i.e., main) and net effects of fertility were estimated under four models. The first model, model 1 estimated gross effects by including only the basic correlates. Models 2 through 4 estimated the net effect of fertility by respectively incorporating the family/composition and household correlates, the economic constraints correlates and the cultural correlates. This sequential incorporation of correlates permits one to monitor the stability of the fertility variable in the presence of successive controls. Thus, each model is more complex than its predecessor as it includes additional controls, as depicted by the regression formula in equation 1 .

$$
\begin{aligned}
& \log Y /(1-Y)=\beta_{0}+\beta_{\mathrm{f}} F+\beta_{b} B+\beta_{f} H+\beta_{e} E \\
+ & \beta_{c} C+\varepsilon \quad \text { Equation } 1
\end{aligned}
$$

where $\log (Y /(1-Y)$ is the log odds of being employed; $F$ is the measure for fertility (bivariate model); $B$ measures the basic correlates (Model 1); $\mathrm{H}$ measures the family composition/household structural correlates (Model 2); E measures the economic constraints correlates (Model 3); C measures the cultural correlate (Model 4); $\varepsilon$ is the error term and the $\beta s$ are the regression coefficients for these correlates, with $\beta_{0}$ being the intercept.

While logistic regression estimates the absolute magnitude of the fertility effects on employment, decomposition methods are used to estimate these effects in relative terms, allowing one to quantify the relative contribution of fertility as opposed to other factors to employment changes. The total change in women's employment between 1991 and 2005 within each country was derived from predicted employment logits using the regression coefficients. Regression decomposition was used to apportion this total change into three components: changes in average fertility (TFR) levels; changes in the employment returns to fertility and changes in the effects of the baseline, which is also the constant. This baseline component reflects country-specific influences that govern women's employment opportunities not included in the analysis, essentially the residual. Changes in TFR levels denote the effect of fertility transition on employment while the 
employment returns to fertility denote the effect of a woman's fertility or family size on her employment behavior. Equation 2 shows these three components:

$$
\begin{array}{r}
\Delta \mathrm{Y}=\Delta \alpha+(\bar{X} * \Delta \beta)+(\bar{B} * \Delta \mathrm{X}) \\
\text { Equation } 2
\end{array}
$$

Where, within any country, $\Delta Y$ is the total change in employment over the two periods of study; ( $\bar{X}$ ${ }^{*} \Delta \beta$ ) is the component due to changes in the returns to fertility; ( $\bar{B} * \Delta \mathrm{X}$ ) is the component of the change due to changes in the effect of the transition; and $\Delta \alpha$ is the baseline component stemming from changes in country-wide employment opportunities.

\section{Results, Discussion and Conclusion}

Results

Given the large number of countries studied and their diversity, study countries were classified into four regimes on the basis of their TFR and employment profiles namely: high fertility-low employment (HFLE); high fertility-high employment
(HFHE); low fertility-low employment (LFLE); and low fertility-high employment (LFHE). Countries under HFLE and LFHE regimes fall on either end of the fertility-employment transition in the sense that the former have yet to initiate its transition as opposed to the latter where the transition is relatively advanced. On the other hand, the HFHE and LFLE regimes fall on opposite sides on intermediate locations of the continuum by having initiated one but not both aspects of the transition.

\begin{tabular}{|c|c|c|c|c|c|c|c|c|c|c|c|c|c|c|c|c|c|c|c|}
\hline \multirow[b]{3}{*}{$\begin{array}{l}\text { Countries } \\
\text { and types }\end{array}$} & \multicolumn{7}{|c|}{ Panel 1: Fertility } & \multicolumn{6}{|c|}{ Panel 2: Employment Levels } & \multicolumn{6}{|c|}{$\begin{array}{l}\text { Panel 3: Bivariate returns to fertility } \\
\text { (no. of living children), odds ratios }\end{array}$} \\
\hline & \multicolumn{2}{|c|}{ Survey sample } & \multicolumn{2}{|c|}{ Survey period } & \multirow[b]{2}{*}{$\begin{array}{c}\text { Time } \\
\text { span/mean }\end{array}$} & \multicolumn{2}{|c|}{$\begin{array}{l}\text { Total fertility } \\
\text { Rate }\end{array}$} & \multicolumn{3}{|c|}{ Overall } & \multicolumn{3}{|c|}{ Skilled } & \multicolumn{3}{|c|}{ Overall } & \multicolumn{3}{|c|}{ Skilled } \\
\hline & $\begin{array}{l}\text { Study } \\
{[1]}\end{array}$ & $\begin{array}{l}\text { Study } \\
\text { [2] }\end{array}$ & $\begin{array}{l}\text { Study } \\
{[1]}\end{array}$ & $\begin{array}{l}\text { Study } \\
\text { [2] }\end{array}$ & & $\begin{array}{c}\text { Study } \\
{[1]}\end{array}$ & $\begin{array}{c}\text { Study } \\
{[2]}\end{array}$ & $\begin{array}{c}\text { Study } \\
{[1]}\end{array}$ & $\begin{array}{l}\text { Study } \\
\text { [2] }\end{array}$ & $\begin{array}{c}\begin{array}{c}\text { Annual } \\
\text { change, } \\
\%\end{array} \\
\end{array}$ & $\begin{array}{c}\text { Study } \\
{[1]}\end{array}$ & $\begin{array}{c}\text { Study } \\
{[2]}\end{array}$ & $\begin{array}{c}\text { Annual } \\
\text { change, } \\
\%\end{array}$ & $\begin{array}{c}\text { Study } \\
{[1]}\end{array}$ & $\begin{array}{c}\text { Study } \\
{[2]}\end{array}$ & $\begin{array}{c}\text { Annual } \\
\text { change, } \\
\%\end{array}$ & $\begin{array}{c}\text { Study } \\
{[1]}\end{array}$ & $\begin{array}{c}\text { Study } \\
\text { [2] }\end{array}$ & $\begin{array}{c}\text { Annual } \\
\text { change, } \\
\%\end{array}$ \\
\hline \multicolumn{20}{|c|}{ High Fertility - Low Employment Regime } \\
\hline Burkina Faso & 6354 & 12477 & 1992 & 2003 & 11 & 6.98 & 6.55 & 83.65 & 22.10 & -10.58 & 5.11 & 10.89 & 6.57 & 0.92 & 1.07 & 0.014 & 1.11 & 1.28 & 0.013 \\
\hline Chad & 7454 & 6085 & 1996 & 2004 & 8 & 7.36 & 7.00 & 32.37 & 18.53 & -6.80 & 4.31 & 25.44 & 17.75 & 1.15 & 1.20 & 0.005 & 1.30 & 1.14 & -0.016 \\
\hline Malawi & 4849 & 13220 & 1992 & 2000 & 8 & 7.72 & 6.83 & 19.43 & 19.71 & 0.18 & 13.06 & 22.76 & 6.77 & 1.14 & 1.28 & 0.015 & 0.83 & 1.18 & 0.043 \\
\hline Rwanda & 6551 & 10421 & 1992 & 2000 & 8 & 6.38 & 6.85 & 6.08 & 10.97 & 7.18 & 43.22 & 35.77 & -2.36 & 0.96 & 0.69 & -0.040 & 1.11 & 0.61 & -0.072 \\
\hline Tanzania & 9238 & 10329 & 1992 & 2004 & 12 & 6.47 & 5.96 & 15.33 & 17.84 & 1.26 & 16.15 & 22.48 & 2.73 & 1.29 & 1.06 & -0.016 & 1.09 & 0.86 & -0.020 \\
\hline Uganda & 7070 & 7246 & 1995 & 2001 & 6 & 7.13 & 6.95 & 16.58 & 18.26 & 1.61 & 37.12 & 22.77 & -7.99 & 1.12 & 1.19 & 0.010 & 1.10 & 0.89 & -0.035 \\
\hline Zambia & 7060 & 7658 & 1992 & 2002 & 10 & 6.79 & 5.67 & 33.07 & 23.84 & -3.24 & 30.30 & 20.57 & -3.83 & 1.51 & 1.42 & -0.006 & 0.94 & 1.12 & 0.017 \\
\hline \multirow{2}{*}{ Sub-sample } & 54836 & 75385 & & & 9 & & & & & & & & & & & & & & \\
\hline & \multicolumn{4}{|c|}{ Average within type } & & 6.87 & 6.45 & 29.04 & 19.16 & -4.37 & 25.02 & 22.01 & -1.37 & 1.16 & 1.14 & -0.002 & 1.08 & 1.04 & -0.004 \\
\hline \multicolumn{20}{|c|}{ High Fertility - High Employment Regime } \\
\hline Benin & 5491 & 6219 & 1996 & 2001 & 5 & 6.47 & 6.09 & 63.43 & 53.92 & -3.24 & 9.22 & 16.93 & 11.78 & 1.19 & 1.49 & 0.045 & 0.58 & 0.76 & 0.054 \\
\hline Senegal & 6310 & 14602 & 1993 & 2005 & 12 & 6.57 & 5.66 & 28.82 & 33.57 & 1.27 & 15.99 & 18.23 & 1.09 & 1.06 & 1.10 & 0.003 & 0.89 & 0.87 & -0.002 \\
\hline \multirow[t]{2}{*}{ Sub-sample } & 28008 & 41247 & & & 7 & & & & & & & & & & & & & & \\
\hline & \multicolumn{4}{|c|}{ Average within type } & & 7.22 & 6.87 & 37.32 & 37.99 & 0.24 & 22.24 & 20.02 & -1.40 & 1.08 & 1.14 & 0.007 & 0.94 & 0.87 & -0.010 \\
\hline \multicolumn{20}{|c|}{ Low Fertility - Low Employment Regime } \\
\hline Cameroon & 3871 & 10656 & 1991 & 2004 & 13 & 5.89 & 5.04 & 24.59 & 29.83 & 1.48 & 9.14 & 15.25 & 3.86 & 1.33 & 1.40 & 0.004 & 1.09 & 0.86 & -0.018 \\
\hline Ethiopia & 15367 & 14070 & 1992 & 1997 & 5 & 5.69 & 6.16 & 26.09 & 16.21 & -9.35 & 39.43 & 20.71 & -12.45 & 0.93 & 1.00 & 0.014 & 1.18 & 1.25 & 0.011 \\
\hline Mozambique & 8779 & 12418 & 1997 & 2003 & 6 & 5.60 & 5.92 & 9.79 & 15.35 & 7.37 & 19.93 & 14.07 & -5.75 & 1.43 & 1.37 & -0.007 & 0.89 & 1.25 & 0.056 \\
\hline \multirow[t]{2}{*}{ Sub-sample } & 28017 & 37144 & & & 9 & & & & & & & & & & & & & & \\
\hline & & Average & e within & type & & 5.69 & 5.76 & 20.78 & 19.83 & -0.54 & 29.13 & 16.92 & -6.10 & 1.14 & 1.24 & 0.010 & 1.08 & 1.14 & 0.006 \\
\hline Low Fertility - & - High Er & mployme & ent Regii & & & & & & & & & & & & & & & & \\
\hline Cote d'lvoire & 8099 & 3040 & 1994 & $\overline{1} 999$ & 5 & 5.56 & 5.06 & 38.73 & 42.67 & 1.93 & 7.28 & 10.80 & 7.79 & 1.11 & 0.96 & -0.029 & 0.77 & 0.90 & 0.030 \\
\hline Ghana & 9405 & 5691 & 1993 & 2003 & 10 & 5.12 & 4.63 & 45.99 & 49.67 & 0.77 & 32.49 & 30.79 & -0.5 & 1.43 & 1.55 & 0.009 & 0.82 & 0.94 & 0.013 \\
\hline Kenya & 7540 & 8195 & 1993 & 2003 & 10 & 5.56 & 5.27 & 58.51 & 31.71 & -5.94 & 22.90 & 12.90 & -5.58 & 0.88 & 1.17 & 0.028 & 1.19 & 1.38 & 0.015 \\
\hline Namibia & 5421 & 6755 & 1992 & 2000 & 8 & 5.60 & 4.40 & 32.36 & 31.94 & -0.16 & 19.71 & 26.37 & 3.61 & 1.60 & 2.24 & 0.041 & 1.06 & 1.27 & 0.023 \\
\hline Nigeria & 9810 & 7620 & 1999 & 2003 & 4 & 5.13 & 6.43 & 32.59 & 46.26 & 8.67 & 19.96 & 22.10 & 2.54 & 2.15 & 1.63 & -0.069 & 0.97 & 0.99 & 0.004 \\
\hline Zimbabwe & 6128 & 5907 & 1994 & 1999 & 5 & 4.55 & 3.73 & 32.91 & 33.49 & 0.34 & 40.03 & 30.15 & -5.63 & 1.44 & 1.44 & -0.001 & 1.58 & 1.43 & -0.019 \\
\hline Sub-sample & 46403 & 37208 & & & 7 & & & & & & & & & & & & & & \\
\hline & & Average & e within & type & & 5.25 & 4.99 & 40.60 & 38.66 & -0.70 & 23.39 & 22.53 & -0.53 & 1.459 & 1.541 & 0.008 & 1.033 & 1.181 & 0.019 \\
\hline Total Sample & 157264 & 190984 & & & & & & & & & & & & & & & & & \\
\hline
\end{tabular}

TABLE1. LEVELS AND TRENDS IN TOTAL FERTILITY RATE(TFR), WOMEN'S LABOR FORCEPARTICIPATION, AND RETURNS TO FERTILTTY WITHIN THE OVERALL AND SKILLED SECTORS IN 21 DHS COUNTRIES IN S 
These regimes therefore reflect various stages in the fertility transition as it relates to employment. Table 1 indicates that the majority of the sample falls under the HFLE (38\%) and LFHE (29\%) while the HFHE and LFLE regimes respectively house $19 \%$ and $14 \%$ of the sample.

Status and patterns of African fertility regimes

Table 1 reviews overall levels and trends in TFR (panel 1) and women's labor force participation (panel 2) during the study period (1991-2005). Focusing on the bottom of panel 1 and on the second study, the TFR for the entire region is 6.1 but countries diverge from this aggregate with fertility levels ranging from a high of 7.2 to a low of 4.0 children per woman. This quick assessment suggests diversity at the regime level as well as between countries. For instance, as expected, fertility levels are lowest in the LFHE regime and highest in the HFHE and HFLE regimes, with the LFLE regime recording moderate levels. Yet within each regime, countries differ greatly in their fertility profiles. Under the HFHE regime, fertility generally ranges from 5.6 children in Benin to 7.2 children in $\mathrm{N}$ iger, recording the highest fertility in the region. $\mathrm{A}$ similar pattern holds under the HFLE regime where the range is from 5.2 (Madagascar) to 6.9 (U ganda) children per woman. Under the LFLE regime where fertility levels are reasonably lower, diversity is also visible with women in Cameroon generally bearing 5 children while Ethiopian women generally average 6.2 children. Finally under the more advanced regime where fertility is relatively low, the range is from 4 children in Zimbabwe (the lowest in the region) to 5.7 children in Nigeria. Given this substantial diversity, it is important to assess trends in fertility levels that led to this recent and very diverse picture.

As the forerunners of the transition, the LFHE regime records the steepest annual decline during the study interval. This steep progress in the transition is also reflected within the regime in most member countries (notably Namibia, Ghana, Kenya and Zimbabwe). Yet, between 1998 and 2003, fertility stalled in Ghana and Kenya (Bongaarts 2006; Shapiro and Gebreselassie 2008) and between 1998 and 2004 in Cameroon (Shapiro and Gebreselassie 2008). Interestingly, the fertility declines are not restricted to the vanguards of the transition. Appreciable declines have also been recorded under the regimes that have barely (HFHE) or have not (HFLE) initiated their transitions. In particular, all countries under the HFLE regime (except $U$ ganda) recorded declines; this is not surprising given the existence of room for such progress. The most interesting trends come from the LFLE regime. Although TFR is generally declining in Cameroon, fertility levels in the other two member countries (Ethiopia and Mozambique) have risen, perhaps due to their histories of political unrest, an occurrence usually followed by rising fertility to replace past loss of lives. Similarly, Mali and $N$ iger stand out under the HFHE regime in that fertility levels have also risen. $N$ onetheless, these results indicate that an incipient transition is underway in the region. In the paragraph that follows, I examine levels and trends in employment within these regimes.

Panel 2 of the table displays levels and trends in women's overall and skilled labor market activity by fertility regimes. The record in each sector is mixed among regimes and countries, with some countries registering declines and others showing gains. In terms of overall paid employment, levels are highest under the LFHE regime and lowest under the LFLE regime. Similarly, skilled sector employment levels are highest under the LFHE regime, but also surprisingly high under the HFLE regime but country profiles differ in each regime and within both labor markets. Finally, three important trends are visible throughout the paid labor force. First, employment levels generally declined across all regimes in both sectors. Second, the overall sector declines are most dramatic under the HFLE regime, partly due to its large sub-sample size. $\mathrm{O}$ the other hand, the skilled sector declines are steepest under the LFLE regime. In spite of the clearly discernible internal regime diversity and contrasting the growing heterogeneity with respect to the fertility transition, the calculated coefficient of variation (bottom row of Table 1) indicates that countries are converging in their employment records. It remains to be seen whether the observed declines in fertility will be translated into improved employment prospects for women. These relationships are examined in subsequent chapters beginning with macro associations. 
African Population Studies Vol 28 no 2 Supplement July 2014

\section{Figure 1. Macro-level Correlations of fertility and employment}

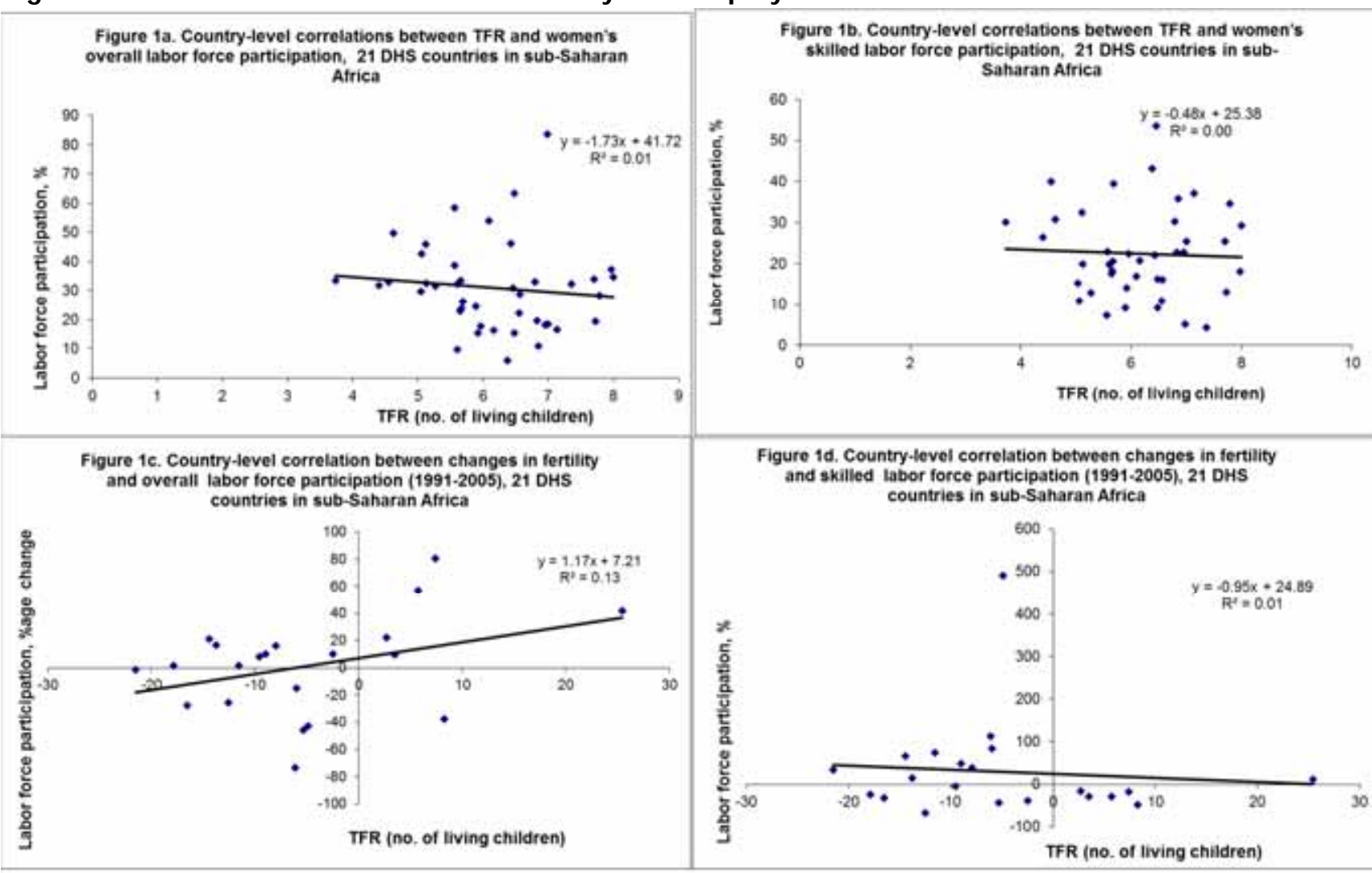

Figure 1e. Country-specific trends between TFR and women's overall labor force participation (1991. 2005), 21 DHS countries in sub-Saharan Africa

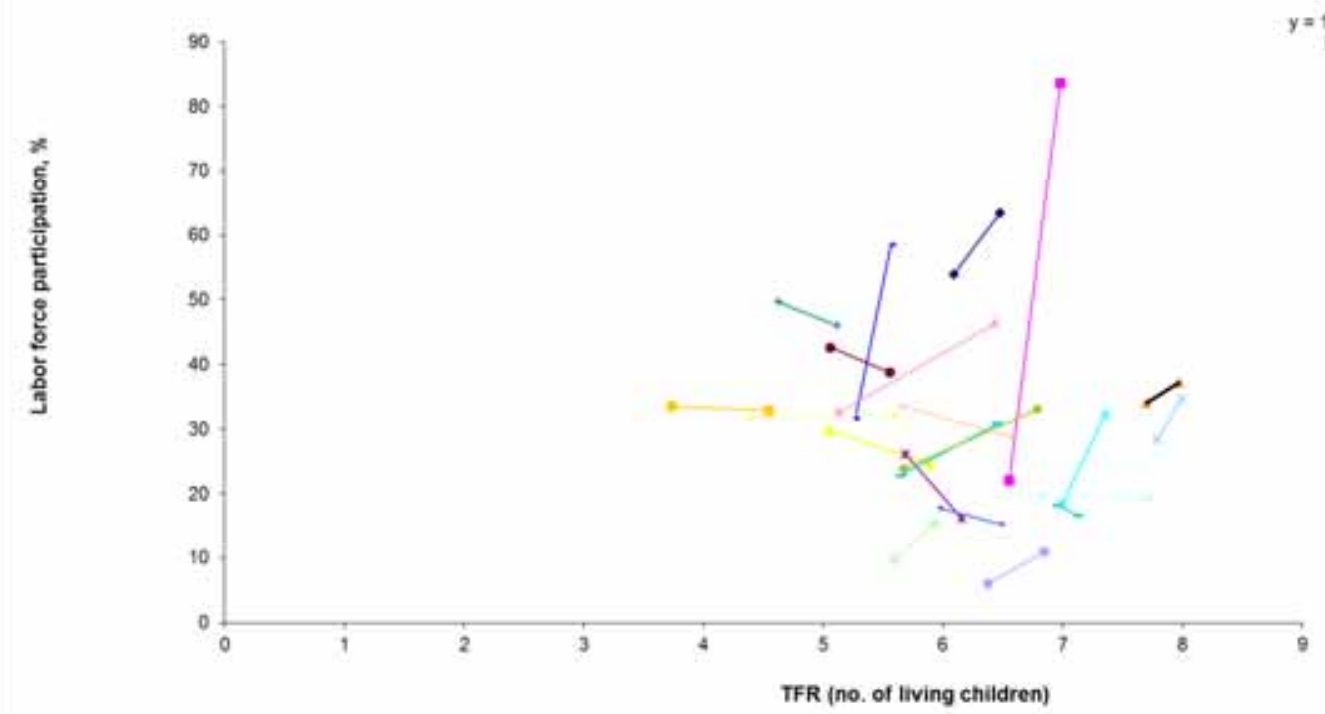

\begin{tabular}{|c|c|c|c|c|c|c|c|}
\hline$\rightarrow$ Benin & - Bucina Faso & Cameroon & -Chad & $\rightarrow$ - Cote divoies & - Enicpia & $\rightarrow$ Ghana & -Kenya \\
\hline - Matopascar & Naraw & Motambique & Namibia & Niger & - Nigeria & $\rightarrow$-Rwanda & - Senegal \\
\hline -Tantmia & -Ueands & - Zambia & - Zmbative & $\rightarrow$ Mai & - Linex (Mali) & & \\
\hline
\end{tabular}


Macro level relationships

Figures 1a-b present country-level associations between TFR and women's employment in the overall and skilled sectors, respectively in the 21 sampled countries across the two studies (19912005). As expected, fertility is inversely related to both overall employment (figure 1a) and skilled employment (figure 1b), but the relationships are weak as indicated by the low $R^{2} s$ suggesting that influential factors have been omitted. A finer understanding of this cross-country relationship can be achieved by examining the correlation between changes in both variables. Results suggest clearer differences in the relationship between the two sectors. It is positive in the overall sector (figure 1c) and negative within the skilled sector (figure 1d), implying that fertility facilitates women's overall employment work but hinders their skilled sector employment. Even more detail can be obtained by looking at changes in the relationship within individual countries (figure 1e) where each line refers to a country and the two points of the line to the respective survey period. The figure shows clear-cut variation across countries, as reflected in the diversity of the lines in terms of timing, slope, interval, and direction of the changes. Thus, any inference from macro findings derived from standard cross-country correlations to individual employment behavior would ignore these historical and cross-country variations, leading to historical (Thornton 2001) and ecological (Eloundou-Enyegue 2011; Robinson 1950) fallacies. These variations in contextual issues are addressed in the multivariate micro-level analyses.
Micro level relationships

Panel 3 of table 1 shows the bivariate associations between fertility and employment. At the regional and regime levels, estimates show positive returns in both the first and second studies for the overall as well as the skilled sectors. With a few exceptions (notably Rwanda and Cote d'Ivoire where the returns have been mostly negative throughout), the same picture is visible at the level of country. This evidence contradicts the macro associations, further highlighting the limitations of relying on macroevidence to infer individual behavior. The bivariate returns are much weaker in the skilled labor market. At the very least and barring the HFHE regime where the skilled returns are mostly negative, these bivariate associations hint that fertility may not, surprisingly, interfere with skilled employment; surprising because this is the sector where conflict between mother and worker roles is most likely to exist. Changes in the bivariate returns also vary across sectors and regimes. Less progress is observed in the skilled than overall sector. Within both sectors, the sharpest changes have occurred in the two end regimes: the LFHE regime registered the largest gains while the HFLE regime registered the steepest decline, suggesting that progress in both transitions foster employment opportunities. Yet, these associations are bivariate and did not control for influential correlates. The next set of multivariate findings controlled for these influential factors. For brevity, and given that the incompatibility thesis is being tested, only the findings from the more restrictive skilled sector where work and mothering conflict is more likely to occur are presented from the multivariate and decomposition analyses. Corresponding results on the overall sector is available on request. 
TABLE 2. TRENDS IN NET RETURNS TO FERTILITY (NO. OF LIVING CHILDREN) WITHIN THE SKILLED SECTOR, 16 DHS COUNTRIES IN SSA, 1991-2005

\begin{tabular}{|c|c|c|c|c|c|c|c|c|c|c|c|c|c|c|c|c|c|c|c|c|c|}
\hline & & & & & & \multicolumn{16}{|c|}{ Skilled Employment } \\
\hline & & & & & & \multicolumn{7}{|c|}{ Panel 1: Study [1] } & \multicolumn{9}{|c|}{ Panel 2: Study [2] } \\
\hline & & & & & & \multicolumn{7}{|c|}{ Logistic regression } & \multicolumn{6}{|c|}{ Logistic regression } & & & \\
\hline & \multicolumn{2}{|c|}{ Survey } & \multicolumn{2}{|c|}{ Survey } & & $\begin{array}{r}\text { Basic } \\
\text { Contro }\end{array}$ & $\begin{array}{l}\text { ic } \\
\text { rols }\end{array}$ & $\begin{array}{c}\text { Family } \\
\text { compositio }\end{array}$ & & $\begin{array}{r}\text { Economic } \\
\text { constraint }\end{array}$ & & Cultural & $\begin{array}{r}\text { Basi } \\
\text { Contro }\end{array}$ & & $\begin{array}{r}\text { Family } \\
\text { composit }\end{array}$ & $\begin{array}{l}y \\
\text { tion }\end{array}$ & $\begin{array}{c}\text { Econom } \\
\text { constrain }\end{array}$ & $\begin{array}{l}\text { mic } \\
\text { ints }\end{array}$ & Cultural & \multicolumn{2}{|l|}{$\begin{array}{c}\text { Fixed } \\
\text { effects }\end{array}$} \\
\hline & \multicolumn{2}{|c|}{ sample } & \multicolumn{2}{|c|}{ period } & & \multicolumn{2}{|c|}{ Model 1} & \multicolumn{2}{|l|}{ Model 2} & \multicolumn{2}{|l|}{ Model 3} & Model 4 & \multicolumn{2}{|c|}{ Model 1} & \multicolumn{2}{|c|}{ Model 2} & \multicolumn{2}{|c|}{ Model 3} & Model 4 & \multicolumn{2}{|c|}{ Model 5} \\
\hline $\begin{array}{l}\text { Countries } \\
\text { and types }\end{array}$ & $\begin{array}{c}\text { Study } \\
\text { [1] }\end{array}$ & $\begin{array}{c}\text { Study } \\
\text { [2] }\end{array}$ & $\begin{array}{c}\text { Study } \\
\text { [1] } \\
\end{array}$ & $\begin{array}{c}\text { Study } \\
\text { [2] } \\
\end{array}$ & $\begin{array}{l}\text { Time } \\
\text { span }\end{array}$ & $\begin{array}{l}\text { Odds } \\
\text { Ratio S } \\
\end{array}$ & Sig & $\begin{array}{l}\text { Odds } \\
\text { Ratio } \\
\end{array}$ & Sig & $\begin{array}{l}\text { Odds } \\
\text { Ratio } \\
\end{array}$ & Sig & $\begin{array}{ll}\text { Odds } & \\
\text { Ratio } & \text { Sig } \\
\end{array}$ & $\begin{array}{r}\text { Odds } \\
\text { Ratio } \\
\end{array}$ & Sig & $\begin{array}{l}\text { Odds } \\
\text { Ratio } \\
\end{array}$ & Sig & $\begin{array}{l}\text { Odds } \\
\text { Ratio }\end{array}$ & Sig & \begin{tabular}{l|l} 
Odds & \\
Ratio & Sig \\
\end{tabular} & $\begin{array}{l}\text { Odds } \\
\text { Ratio S } \\
\end{array}$ & Sig \\
\hline \multicolumn{22}{|c|}{ High Fertility - Low Employment Regime } \\
\hline Burkina Faso & 6354 & 12477 & 1992 & 2003 & 11 & 1.14 & & 1.06 & & 1.02 & & 1.02 & 0.94 & & 0.90 & ** & 0.90 * & ** & 0.90 * & 0.94 & \\
\hline Chad & 7454 & 6085 & 1996 & 2004 & 8 & 0.99 & & 0.93 & & 0.94 & & 0.93 & 1.06 & & 1.07 & & 1.07 & & 1.08 * & 1.07 & \\
\hline Madagascar & 6260 & 7949 & 1992 & 2004 & 12 & 0.96 & & 0.95 & & 0.97 & & 0.97 & 1.04 & & 1.03 & & 1.01 & & 1.01 & 1.00 & \\
\hline Tanzania & 9238 & 10329 & 1992 & 2004 & 12 & 0.70 * & & 0.66 & *** & 0.59 * & *** & $0.59^{* * *}$ & 0.99 & & 0.96 & & 0.96 & & 0.95 & 0.92 & \\
\hline Uganda & 7070 & 7246 & 1995 & 2001 & 6 & 1.06 & & 0.99 & & 0.98 & & 0.97 & 0.99 & & 0.98 & & 0.97 & & 0.97 & 0.95 & \\
\hline Zambia & 7060 & 7658 & 1992 & 2002 & 10 & 0.86 * & & 0.84 & & 0.83 * & & 0.82 ** & 0.96 & & 0.94 & & 0.94 & & 0.95 & 0.92 & \\
\hline Sub-sample & 43436 & 51744 & & & 10 & & & & & & & & & & & & & & & & \\
\hline & & & Averas & ge with & in type & 0.94 & & 0.89 & & 0.87 & & 0.87 & 0.99 & & 0.97 & & 0.96 & & 0.97 & 0.96 & \\
\hline High Fertility - & - High E & Employm & ent $\operatorname{Rec}$ & gime & & & & & & & & & & & & & & & & & \\
\hline Benin & 5491 & 6219 & 1996 & 2001 & 5 & 0.59 * & *** & 0.65 & *** & 0.61 * & *** & 0.58 *** & 0.85 & *** & 0.84 & *** & 0.84 * & *** & $0.82 * * *$ & 0.80 * & *** \\
\hline Mali & 9704 & 12849 & 1996 & 2001 & 5 & 0.98 & & 0.94 & & 0.94 & & 0.94 & 0.97 & & 0.98 & & 0.97 & & 0.98 & 0.97 & \\
\hline Niger & 6503 & 7577 & 1992 & 1998 & 6 & 1.08 & & 1.13 & & 1.15 & & 1.13 & 0.97 & & 1.00 & & 1.01 & & 1.05 & 1.00 & \\
\hline Senegal & 6310 & 14602 & 1993 & 2005 & 12 & 0.82 * & & 0.80 & & 0.82 * & & 0.82 * & 0.85 & *** & 0.85 & *** & 0.85 * & *** & $0.85^{* * *}$ & 0.84 * & *** \\
\hline Sub-sample & 28008 & 41247 & & & 7 & & & & & & & & & & & & & & & & \\
\hline & & & Averas & ge with & in type & 0.89 & & 0.90 & & 0.90 & & 0.89 & 0.91 & & 0.91 & & 0.92 & & 0.92 & 0.90 & \\
\hline Low Fertility - & Low En & nployme & nt Regi & ime & & & & & & & & & & & & & & & & & \\
\hline Cameroon & 3871 & 10656 & 1991 & 2004 & 13 & 1.12 & & 1.18 & & 1.16 & & 1.17 & 0.96 & & 0.95 & & 0.95 & & 0.95 & 0.93 & \\
\hline Mozambique & 8779 & 12418 & 1997 & 2003 & 6 & 0.97 & & 0.96 & & 0.93 & & 0.93 & 1.00 & & 1.00 & & 1.00 & & 1.00 & 0.91 & \\
\hline Sub-sample & 12650 & 23074 & & & 10 & & & & & & & & & & & & & & & & \\
\hline & & & Averas & ge with & in type & 1.01 & & 1.03 & & 1.00 & & 1.01 & 0.98 & & 0.98 & & 0.97 & & 0.98 & 0.92 & \\
\hline Low Fertility - & High E & mployme & nt Reg & gime & & & & & & & & & & & & & & & & & \\
\hline Cote d'Ivoire & 8099 & 3040 & 1994 & 1999 & 5 & 0.79 * & & 0.78 & & 0.80 * & & 0.78 * & 0.87 & & 0.87 & * & 0.87 * & * & 0.86 * & 0.86 * & \\
\hline Ghana & 9405 & 5691 & 1993 & 2003 & 10 & 0.82 * & *** & 0.77 & *** & 0.80 * & *** & $0.78^{* * *}$ & 1.00 & & 0.98 & & 0.97 & & 0.97 & 0.95 & \\
\hline Nigeria & 9810 & 7620 & 1999 & 2003 & 4 & 0.93 * & *** & 0.92 & & 0.95 & & 0.94 & 0.99 & & 0.99 & & 0.98 & & 1.00 & 0.96 & \\
\hline Zimbabwe & 6128 & 5907 & 1994 & 1999 & 5 & 1.09 & & 1.02 & & 1.03 & & 1.04 & 1.01 & & 1.02 & & 1.01 & & 1.03 & 1.03 & \\
\hline Sub-sample & 33442 & 22258 & & & 6 & & & & & & & & & & & & & & & & \\
\hline & & & Averas & ge with & in type & 0.89 & & 0.86 & & 0.88 & & 0.88 & 0.98 & & 0.98 & & 0.97 & & 0.98 & 0.96 & \\
\hline Total Sample & \#\#\#\# & 95851 & & & & & & & & & & & & & & & & & & & \\
\hline & & & & AVERA & & 0.92 & & 0.90 & & 0.89 & & 0.89 & 0.96 & & 0.95 & & 0.95 & & 0.96 & 0.94 & \\
\hline & & & & INEQU & ALITY & 0.02 & & 0.02 & & 0.03 & & 0.03 & 0.00 & & 0.00 & & 0.00 & & 0.00 & 0.00 & \\
\hline
\end{tabular}

P-values: ***, **, and * indicate significance at the $<0.001,0.01$, and 0.05 levels, respectively.

A quick gloss over the net results (i.e., adjusting for controls) in table 2 (panel 1) indicates that in the initial study period fertility was negatively related to women's skilled employment in quite a few countries across the regimes (Tanzania, Zambia, Benin, Senegal, Cote d'Ivoire and Ghana) where mothers were less likely than non-mothers to access this sector. In the remaining study countries, fertility was unrelated to women's skilled employment behavior in the early 1990s. Table 2 (panel 2) reports the recent estimates of the relationship as measured by the second study. These more recent skilled sector associations reveal the effect of fertility to be, unexpectedly, small in magnitude in all but a handful of countries irrespective of regime or the presence of correlates. Fertility impedes women's odds of engaging in skilled work in Burkina Faso (HFLE regime), Benin and Senegal under the HFHE regime and in Cote d'Ivoire under the LFHE regime but increases the odds in Chad. But that's about it. In the remaining sample, mothers are no less disadvantaged than non-mothers in accessing skilled work.

To sum up, in most cases, the relationship between fertility and skilled employment in recent times is largely non-existent, being not only very small in the size of the estimate but also statistically non-significant. As the transition advances in the fourth regime, the net effect becomes undeniably small. Transcending countries' stage in the fertility employment transition, there appears to be a geographic effect: all the few cases where fertility hindered women's skilled work opportunities in recent times are located in the West African subregion. Further, the role of correlates on the fertility and skilled employment relationship has become 
more marked in contemporary times to the point that it reduced (Tanzania, Zambia, Benin, Senegal) or eliminated (Ghana) the disadvantage faced by mothers relative to non-mothers in earlier times. The decline in the relative edge of non-mothers can plausibly stem from the economic structural adjustment reforms that have been reported to generally favor men over women (Beneria and mothers and non-mothers.
Feldman 1992) rather than stemming from a differential impact of fertility. This explanation becomes even more plausible in the case of Burkina Faso and $C$ had where unmeasured factors (model 5), which may well include the economic reforms or economic growth, fully explain the employment differential

TABLE 3. RELATIVE CONTRIBUTION OF FERTILITY TO CHANGES IN WOMEN'S SKILLED EMPLOYMENT IN 21 DHS COUNTRIES IN SSA, 1991-2005

\begin{tabular}{|c|c|c|c|c|c|c|c|c|c|c|c|c|}
\hline \multirow[b]{3}{*}{$\begin{array}{l}\text { Countries } \\
\text { and types }\end{array}$} & \multirow{2}{*}{\multicolumn{3}{|c|}{ Sample size }} & \multirow[b]{3}{*}{$\begin{array}{c}\text { Study } \\
{[1]}\end{array}$} & \multirow[b]{3}{*}{$\begin{array}{c}\text { Study } \\
\text { [2] }\end{array}$} & \multirow[b]{3}{*}{$\begin{array}{l}\text { Time } \\
\text { span }\end{array}$} & \multicolumn{6}{|c|}{ Predicted Employment (logits) in the Skilled Sector } \\
\hline & & & & & & & \multirow[b]{2}{*}{$\begin{array}{c}\text { Study } \\
{[1]}\end{array}$} & \multirow[b]{2}{*}{$\begin{array}{l}\text { Study } \\
\text { [2] }\end{array}$} & \multirow[b]{2}{*}{$\begin{array}{c}\begin{array}{c}\text { Total } \\
\text { change }\end{array} \\
\end{array}$} & \multicolumn{3}{|c|}{$\begin{array}{l}\text { Percent of total change } \\
\text { associated with }\end{array}$} \\
\hline & $\begin{array}{c}\text { Study } \\
{[1]}\end{array}$ & $\begin{array}{c}\text { Study } \\
{[2]}\end{array}$ & $\begin{array}{c}\text { Average } \\
\text { sample }\end{array}$ & & & & & & & Baseline & $\begin{array}{c}\text { Total } \\
\text { fertility } \\
\text { rate } \\
\text { (TFR) } \\
\end{array}$ & $\begin{array}{l}\text { Returns to } \\
\text { fertility: } \\
\text { no of living } \\
\text { children }\end{array}$ \\
\hline \multicolumn{13}{|c|}{ GAINS IN EMPLOYMENT } \\
\hline \multicolumn{13}{|c|}{ High Fertility - Low Employment Regime } \\
\hline Burkina Faso & 6354 & 12477 & 9416 & 1992 & 2003 & 11 & -3.09 & -1.85 & 1.24 & $192 \%$ & $-2 \%$ & $-91 \%$ \\
\hline Chad & 7454 & 6085 & 6770 & 1996 & 2004 & 8 & -3.20 & -0.27 & 2.93 & $60 \%$ & $-1 \%$ & $41 \%$ \\
\hline Malawi & 4849 & 13220 & 9035 & 1992 & 2000 & 8 & -4.60 & -0.96 & 3.64 & $29 \%$ & $2 \%$ & $69 \%$ \\
\hline Tanzania & 9238 & 10329 & 9784 & 1992 & 2004 & 12 & -6.95 & -2.75 & 4.19 & $70 \%$ & $3 \%$ & $27 \%$ \\
\hline \multicolumn{13}{|c|}{ High Fertility - High Employment Regime } \\
\hline Benin & 5491 & 6219 & 5855 & 1996 & 2001 & 13 & -59.29 & -3.62 & 55.67 & $98 \%$ & $0 \%$ & $2 \%$ \\
\hline \multicolumn{13}{|c|}{ Low Fertility - Low Employment Regime } \\
\hline Cameroon & 3871 & 10656 & 7264 & 1991 & 2004 & 13 & -5.03 & -2.94 & 2.09 & $160 \%$ & $0 \%$ & $-60 \%$ \\
\hline \multicolumn{13}{|c|}{ Low Fertility - High Employment Regime } \\
\hline Namibia & 5421 & 6755 & 6088 & 1992 & 2000 & 8 & -6.03 & -2.72 & 3.31 & $56 \%$ & $1 \%$ & $43 \%$ \\
\hline Ghana & 9405 & 5691 & 7548 & 1993 & 2003 & 10 & -1.35 & -0.43 & 0.92 & $12 \%$ & $6 \%$ & $82 \%$ \\
\hline Cote d'Ivoire & 8099 & 3040 & 5570 & 1994 & 1999 & 5 & -4.44 & -3.62 & 0.83 & $64 \%$ & $13 \%$ & $23 \%$ \\
\hline \multicolumn{13}{|c|}{ REVERSALS IN EMPLOYMENT } \\
\hline \multicolumn{13}{|c|}{ High Fertility - Low Employment Regime } \\
\hline Madagascar & 6260 & 7949 & 7105 & 1992 & 2004 & 12 & -0.43 & -2.00 & -1.57 & $128 \%$ & $0 \%$ & $-28 \%$ \\
\hline Rwanda & 6551 & 10421 & 8486 & 1992 & 2000 & 8 & -0.98 & -4.98 & -4.00 & $48 \%$ & $2 \%$ & $51 \%$ \\
\hline Zambia & 7060 & 7658 & 7359 & 1992 & 2002 & 10 & -1.31 & -1.42 & -0.11 & $1352 \%$ & $-48 \%$ & $-1203 \%$ \\
\hline Uganda & 7070 & 7246 & 7158 & 1995 & 2001 & & -0.45 & -3.46 & -3.01 & $47 \%$ & $0 \%$ & $54 \%$ \\
\hline \multicolumn{13}{|c|}{ High Fertility - High Employment Regime } \\
\hline Mali & 7070 & 7246 & 7158 & 1996 & 2001 & 6 & -1.33 & -2.44 & -1.11 & $46 \%$ & $1 \%$ & $53 \%$ \\
\hline Niger & 6503 & 7577 & 7040 & 1992 & 1998 & 6 & -0.34 & -2.19 & -1.85 & $-14 \%$ & $1 \%$ & $113 \%$ \\
\hline Senegal & 6310 & 14602 & 10456 & 1993 & 2005 & 12 & -3.00 & -3.17 & -0.16 & $13 \%$ & $-128 \%$ & $215 \%$ \\
\hline \multicolumn{13}{|c|}{ Low Fertility - Low Employment Regime } \\
\hline Ethiopia & 15367 & 14070 & 14719 & 1992 & 1997 & 5 & 0.17 & -1.57 & -1.74 & $68 \%$ & $-4 \%$ & $36 \%$ \\
\hline Mozambique & 8779 & 12418 & 10599 & 1997 & 2003 & 6 & -2.71 & -3.14 & -0.42 & $167 \%$ & $0 \%$ & $-67 \%$ \\
\hline \multicolumn{13}{|c|}{ Low Fertility - High Employment Regime } \\
\hline Kenya & 7540 & 8195 & 7868 & 1993 & 2003 & 10 & -2.62 & -9.34 & -6.72 & $107 \%$ & $0 \%$ & $-7 \%$ \\
\hline Nigeria & 9810 & 7620 & 8715 & 1999 & 2003 & 4 & -2.14 & -2.18 & -0.04 & $8 \%$ & $251 \%$ & $-160 \%$ \\
\hline Zimbabwe & 6128 & 5907 & 6018 & 1994 & 1999 & 5 & -0.79 & -2.66 & -1.87 & $59 \%$ & $0 \%$ & $41 \%$ \\
\hline
\end{tabular}

C an this be interpreted as cause for optimism for women's economic prospects in the region and declining inequality across genders and families? What do these results hold for the fertility transition in the region? Much cannot be said about these changes because they stem from absolute effects and one cannot interpret with certainty the relative contribution of fertility as opposed to other factors to these changes. A more accurate picture from the decomposition procedure is presented below.

Table 3 presents the results of the decomposition exercise within the skilled sector for the 21 countries in the study. The results show a breakdown of the total changes in employment 
between 1991 and 2005 into three components: changes in the employment returns to fertility, changes in the effects of TFR (i.e., the fertility transition) and changes in the baseline effects. Thus, the results show the relative contribution (in percentage terms) of the employment returns to fertility or aggregate fertility levels as opposed to country-specific factors. These country-specific factors are inferred from the baseline and consider countrywide influences besides fertility, not included in the analyses but that impact employment opportunity.

Panel 1 at the top of table 3 presents the total change in employment during the study within each country. Results indicate that women made gains in their access to skilled employment in nine countries. The returns to fertility component is the dominant force behind the gains in only Malawi and Ghana explaining $69 \%$ and $82 \%$ of the respective gains. This means that women with large rather than small family sizes or declining fertility were the driver of the observed progress in employment. In the remaining seven (Burkina Faso, Chad, Tanzania, Benin, Cameroon, Namibia, and Cote d'Ivoire), changes in the baseline component were the main drivers of the gains.

Twelve countries registered declines in women's skilled employment in the region as a whole (bottom of table 5). Among these, the returns to fertility component turned out to be driving the reversals in $\mathrm{N}$ iger and Senegal, and to a lesser extent in Rwanda, U ganda and Mali, implying that large family sizes are causing women to retreat from this presumably more economically secure sector. In the case of $\mathrm{N}$ igeria, the retreat was associated with fertility transition. In the remaining 6 countries (Madagascar, Zambia, Ethiopia, Mozambique, Kenya, Zimbabwe), the baseline mostly was behind the observed reversals.

\section{Discussion and Conclusion}

The above evidence suggests that with a few exceptions, neither fertility transition nor changes in family size were behind much of the progress in women's skilled work in the region between 1991 and 2005. Further, the evidence indicates that women's retreat from the skilled labor force in several countries cannot be attributed to changes in fertility or family size but to baseline-related processes. These processes can be tied to generalized declines in the economy and the consequential increase in: women's reservation to work garnered from qualitative research (Jah 2011), trading quality for quantity (Eloundou-Enyegue
1997) and negative impacts of structural adjustments and privatization (Beneria and Feldman 1992).

How does one interpret the above findings in assessing the merit of the incompatibility thesis and prospects for the fertility transition and family socioeconomic wellbeing? The incompatibility thesis is assessed on the basis of the changes in the skilled sector, where conflict is most likely to occur. The thesis is unsupported in instances where factors related to fertility drive most (Malawi and Ghana) or some (Chad and Namibia) of the gains in skilled work. Beyond the possibility of an unsaturated skilled sector, this positive impact of fertility on skilled sector work can stem from access to buffer from kin or paid childcare by skilled workers. In these countries, policy efforts at two fronts are crucial. First, the evidence in this small group of countries defies the fertility employment logic because it serves to sustain fertility. Thus, strong and acceptable reproductive health programs that ultimately enhances women's access to fertility reduction means to help them further advance their careers are imperative. Second, employment-related programs that ensure women's greater access to and retention in the skilled sector are crucial for their professional development and for reducing gender inequality.

Conversely, and concurring with past work (Shapiro and Tambashe 1997; Lokskin et al. 2000 and to some degree, Beguy 2009) the incompatibility thesis receives support in a larger set of countries where fertility is the main factor behind skilled sector declines: Senegal, Niger, U ganda, and Mali and to a lesser extent and in decreasing order Rwanda, Zimbabwe, Ethiopia, and Nigeria. In these countries and in addition to promoting women's access to skilled sector jobs, reducing the family burden on mothers can ultimately augur their socioeconomic wellbeing and that of their families, which in turn, can have a positive effect on the future course of the transition.

In countries where the baseline is observed to be the driver of the changes in women's skilled sector work, whether gains or reversals the conventional incompatibility thesis is unsupported. Rather the evidence in these countries point to the salience of countrywide processes in women's work lives in this more regulated and restricted skilled sector. It would be insightful to know what aspects of country specific factors constitute the baseline in this large sub-sample of countries, where neither TFR nor returns to fertility adequately explain the fertility employment nexus. While the organization of work 
thesis invoked by Mason and Palan (1981) may be a credible explanation, the national economic environment provides a broader lens in explaining the employment behavior of women. N ext research steps will explore the relative contributions of the statistically significant correlates included in the full analyses here as well as the role of the changing economic situation in countries.

\section{References}

Becker, G. 1992. "Fertility and the Economy." Journal of Population Economics, 5: 185-201.

Beguy, D. 2009. "The Impact of Female Employment on Fertility in Dakar (Senegal) and Lomé (Togo)." Demographic Research, 20(7), 97128.

Beneria, L. and Feldman, S. (eds.). 1992. Unequal Burden: Economic Crises, Persistent Poverty, and Women's W ork. Boulder: Westview Press.

Bloom, D., Canning, D., Fink, G. and Finlay, J. 2009. "Fertility, Female Labor Force Participation, and the Demographic Dividend." Journal of Economic Growth, 14(2), 79-101.

Bongaarts, J. 2002. "The End of the Fertility Transition in the Developing World." Working Paper No. 161. New York: The Population Council.

Bongaarts, J. 2006. "The Causes of Stalling Fertility Transitions." Studies in Family Planning, 37(1), 116.

Bongaarts, J. 2007. "Fertility Transition in the Developing World: Progress or Stagnation?" Paper presented at the Annual Meeting of the Population Association of America, N ew York, NY, March 2007.

Brewster, K.L. and Rindfuss, R.R. 2000. "Fertility and Women's Employment in Industrialized N ations." Annual Review of Sociology, 26: 271-296.

Caldwell, J.C. 1980. "Mass Education as a Determinant of the Timing of Fertility Decline." Population and Development Review, 6(2), 225255.

Caldwell, J. C. 1982. Theory of Fertility Decline. London: Academic Press.

Cohen, B. 1998. "The Emerging Fertility Transition in Sub-Saharan Africa." World Development, 26(8), 1431-1461.

Collver, A. and Langlois, E. 1962. The Female Labor Force in Metropolitan Areas: An International Comparison. Berkeley: The University of California.

Connelly, R., DeGraff, D. and Levinson, D. 1996. "Women's Employment and Child Care in
Brazil." Economic Development and Cultural Change, 44: 619-656.

Cramer, J.C. 1980. "Fertility and Female Employment: Problems of Causal Directions." American Sociological Review, 45(2): 167-190.

Demographic and Health Surveys (DHS), 2013. Statcompiler, ORC Macro. Available online at: http:// www.statcompiler.com accessed August 2013.

Eloundou-Enyegue, P.M. 1997. Demographic Responses to Economic Crisis in Cameroon: Fertility, Child Schooling and The Quantity $\mathrm{Q}$ uality Tradeoff. PhD Thesis. The Pennsylvania State U niversity.

Eloundou-Enyegue, P.M., Stokes, C.S., and Cornwell, G. 2000. "Are There Crisis-Led Fertility Declines? Evidence from Central Cameroon." Population Research and Policy Review, 19(1): 47-72.

Eloundou-Enyegue, P.M. 2011. Effects of Fertility Transitions on Schooling in Sub-Saharan Africa: From Micro-Level to Aggregate Effects. Fifth Annual PopPov Conference on Population, Reproductive Health, and Economic Development, 2011. Available at SSRN : http://ssrn.com/abstract= 1845884.

Garenne, M. and Joseph, V. 2002. "The Timing of the Fertility Transition in Sub-Saharan Africa." W orld Development, (30): 1835-1843.

Gurak, D.T and Kritz, M.M. 1982. "Female Employment and Fertility in the Dominican Republic: a Dynamic Perspective." American Sociological Review, 47(6): 810-818.

Gurak, D.T. and Kritz, M.M. 1996. "Social Context, Household Composition and Employment Among Migrant and Non-migrant Dominican Women". International M igration Review, 30: 399422.

Jah, F. 2007. "Learning to Labor: What Happens to African Women's Employment in the Course of Educational Transitions, 1991-2005" The Current, 10(2): 29-48. Published by Public Policy Journal of the Cornell Institute for Public Affairs.

Jah, F. 2011. "Educational Expansion, Demographic Transitions and Implications for Women's Employment in sub-Saharan Africa (1991-2005): A Multi-method Analysis." PhD Thesis, Cornell U niversity. Ithaca, NY, USA.

Lloyd, C.B. 1991. "The Contribution of the World Fertility Surveys to an Understanding of the Relationship between Women's Work and Fertility. Studies in Family Planning, 22(3): 141161. 
Lloyd, C.B. and Hewett, P.C. 2003. "Primary Schooling in sub-Saharan Africa: Recent Trends and Current Challenges." Policy Research Division Working Paper N o. 176. The Population Council, N ew York.

Lokshin, M., Glinskaya, E. and Garcia, M. 2004 "The Effect of Early Childhood Development Programs on Women's Labor Force Participation and O Ider Children's Schooling in Kenya." Journal of African Economies, 13(2): 240-276.

Mason, K.O. and Palan, V.T. 1981. "Female Employment and Fertility in Peninsular Malaysia: The Maternal Role Incompatibility Hypothesis Reconsidered," Demography, 18(4): 549-575.

Moffitt, R. 2005. "Causal Analysis Relationships in Population Research." Demography, 42(1): 91108.

Moffitt, R. 2003. "Causal Analysis in Population Research: An Economist's Perspective." Population and Development Review, 29(3): 448458.

National Academy of Sciences. 2005. Growing Up Global: The Changing Transitions to Adulthood in Developing Countries. Washington, DC.

Robinson, W.S. 1950. "Ecological Correlations and the Behavior of Individuals." American Sociological Review, 15: 351-57.

Rutstein, S.0. 2002. Fertility Levels, Trends, and Differentials 1995-1999. DHS Comparative Reports No. 3. Calverton, Maryland: ORC Macro.

Schockaert, I. 2005. "Women's Employment and Fertility in Latin America. A Review of the Q uestion." Population, 60(1-2): 149-168.

Shapiro, D. and Tambashe, B.O. 1997. "Education, Employment, and Fertility in Kinshasa and Prospects for Changes in Reproductive Behavior." Population Research and Policy Review, 16(3): 259-287.
Shapiro, D. and Tambashe, B.O. 2002. "Fertility Transition in U rban and Rural Sub-Saharan Africa: Preliminary Evidence of a Three-Stage Process." Journal of African Policy Studies, (8): 103-127.

Shapiro, D. and Gebreselassi, T. 2008. "Fertility Transition in Sub-Saharan Africa: Evidence from the Demographic and Health Surveys." African Population Studies, 22/23(1): 3-23.

Shapiro, D., Gebreselassie, T., and Strunk, L. 2003. "Fertility Transition in Sub-Saharan Africa: Evidence from the Demographic and Health Surveys." Paper presented at the Annual Meeting of the Population Association of America, Minneapolis, May 2003.

Stokes, C.S. and Hsieh, Y.S. 1983. "Female Employment and Reproductive Behavior in Taiwan, 1980." Demography, 20(3): 313-331.

Stycos, J.M. and Weller, R.H. 1967. "Female Working Roles and Fertility." Demography, 4: 210-217.

Thornton, A. 2001. "The Development Paradigm, Reading History Sideways, and Family Change." Demography, 38: 449-465.

UNICEF 2003. The State of the World's Children 2004. Girls, Education and Development. United $N$ ations Children's Fund (UNICEF). Available online at: www unicef.org.

United N ations. 1987. "Women's Employment and Fertility: A Comparative Analysis of Fertility Survey D ata for 38 D eveloping Countries. U nited $\mathrm{N}$ ations, $\mathrm{N}$ ew York.

United $\mathrm{N}$ ations. 2005. The Millennium Development Goals Report. Available online at http:// www.un.org/millenniumgoals. Accessed May 2007.

Westoff, C.F. 2003. Trends in Marriage and Early Childbearing in Developing Countries. DHS Comparative Reports No. 5. Calverton, MD: O RC Macro.

Yousef, N.H. 1972. "Differential Labor Force Participation of Women in Latin America and Middle Eastern Countries: The Influence of Family Characteristic." Social Forces, 51: 135-53. 